\title{
IMPLIKASI KEBERADAAN FRAKSI PARTAI POLITIK DALAM KELEMBAGAAN DPR
}

\author{
Zainal Arifin Hoesein, ${ }^{1}$ Dwi Putri Cahyawati, ${ }^{2}$ dan Eka Widadi ${ }^{3}$ \\ Arifinhoesein55@yahoo.com,dwicahya.putri70@gmail.com, ekawidadi@gmail.com \\ Fakultas Hukum Universitas Muhammadiyah Jakarta \\ Jl. KH. Ahmad Dahlan, Cirendeu, Ciputat, Tangerang Selatan, Banten.
}

\begin{abstract}
Abstrak
Dewan Perwakilan Rakyat sebagai salah satu lembaga parlemen di Indonesia, merupakan lembaga perwakilan rakyat. Hal ini setidaknya tercermin dalam Pasal 20 UUD NRI 1945 yang menegaskan bahwa DPR memegang kekuasaan membentuk undang-undang. Sebagai lembaga perwakilan rakyat, sudah seharusnya setiap anggota DPR menjalankan fungsinya sebagai wakil rakyat. Disaat yang bersamaan, dalam UU No. 2 Tahun 2018 dan UU No. 2 Tahun 2011 dikenal adanya fraksi partai politik dalam kelembagaan DPR. Walaupun keberadaan fraksi ini dimaksudkan untuk pengelompokan anggota berdasarkan konfigurasi partai politik berdasarkan hasil pemilihan umum, namun di sisi lain fraksi juga memiliki kewenangan seperti melakukan pergantian antar waktu (PAW) anggotanya yang duduk sebagai anggota DPR, sehingga hal ini dapat menggangu pelaksanaan fungsi DPR sebagai perwakilan rakyat. Penelitian ini menggunakan metode penelitian normatif. Hasil penelitian menemukan bahwa keberadaan fraksi dalam kelembagaan DPR merupakan kepanjangan partai politik dan hal ini membawa implikasi lain berupa terganggunnya pelaksanaan fungsi perwakilan rakyat oleh setiap anggota DPR menjadi perwakilan partai.
\end{abstract}

Kata Kunci: Fraksi, Partai Politik, dan DPR.

${ }^{1}$ Dosen Tetap Fakultas Hukum Universitas Muhammadiyah Jakarta.

2 Dosen Tetap Fakultas Hukum Universitas Muhammadiyah Jakarta.

${ }^{3}$ Mahasiswa Program Sarjana Fakultas Hukum Universitas Muhammadiyah Jakarta. 


\title{
AL-QISTH LAW REVIEW \\ VOL 5 NO. 1 (2021)
}

\begin{abstract}
The People's representative Council as one of the parliamentary institutions in Indonesia, is a people's representative institution. This is at least reflected in Artivle 20 of the 1945 Constitution wich affirms that the DPR has the power to make laws. As a people's representative institution, every member of the DPR should carry out its function as a people's representative. The implementation of this function was degraded after in act No. 2 of 2018 and act No. 2 of 2011 it is known that there are political party factions in the DPR institution. Although the existence of this factions is intended to group members based on the configuration of political parties based on the results of the general election, on the other hand, the faction also hat the authority to make intertime replacements (PAW) of its members who sit as members of the DPR, so that this can interfere with the implementation of the DPR's functions as representatives people. This research uses normative research methods. The results of the study found that the existence of factions in the DPR institution was an exintension of political parties and this had othe implications in the form of disruption of the implementation of the function of people's representatives by every member of the DPR to become party representatives.
\end{abstract}

Keywords: Faction, Political Party, and DPR.

\section{A. PENDAHULUAN}

\section{a. Latar Belakang Masalah}

Dewan Perwakilan Rakyat merupakan pelembagaan keadaulatan rakyat, sebagaimana ditegaskan dalam pasal 1 ayat (2) Undang-Undang Dasar Negara Republik Indonesia Tahun 1945, yang menentukan: "Kedaulatan berada di tangan rakyat dan dilaksanakan menurut Undang-Undang Dasar". Secara sosiologis keberadaan lembaga Dewan Perwakilan Rakyat sebagai wakil rakyat merupakan amanat dari seluruh rakyat Indonesia yang harus dijalankan. Pada posisinya sebagai wakil rakyat, maka 


\section{AL-QISTH LAW REVIEW \\ VOL 5 NO. 1 (2021)}

hubungan antara rakyat dengan Dewan Perwakilan Rakyat (hubungan antara wakil rakyat dengan pihak yang diwakili dalam hal ini adalah rakyat) merupakan mandat yang harus dijalankan terutama terkait dengan fungsi legislasi Dewan Perwakilan Rakyat.

Pasca perubahan UUD 1945, Dewan Perwakilan Rakyat mendapatkan kekuasaan yang signifikan. Amandemen Pasal 5, 20, dan 21 adalah contoh gamblang pengalihan kekuasaan dari Presiden kepada DPR. Sebelum amandemen Pasal 5 ayat (1) menegaskan bahwa: "Presiden memegang kekuasaan membentuk undang-undang dengan persetujuan DPR". Aturan ini diubah hingga hanya memberikan hak kepada Presiden untuk "mengajukan rancangan undang-undang kepada DPR". Sebuah hak yang dimiliki oleh setiap anggota DPR (Pasal 21 Pasca Amandemen). Lebih jauh lagi DPR mengambil alih kewenangan legislative dari tangan Presiden. Pasal 20 ayat (1) menegaskan bahwa DPR "memgang kekuasaan membentuk Undang-Undang". Walaupun secara procedural harus mendapatkan persetujuan bersama antara DPR dengan Presiden (Pasal 20 ayat (2), (3), dan ayat (4)) (Sirajuddin dan Winardi, 2005).

Di Indonesia, fungsi lembaga perwakilan atau parlemen biasanya dibedakan ke dalam tiga fungsi, yaitu: (i) Fungsi legislasi (legislative); (ii) Fungsi pengawasan (control); dan, (iii) Fungsi anggaran (budget). Ketiga fungsi ini diatur dengan jelas dalam Undang-Undang tentang Susunan dan Kedudukan MPR, DPR, DPD, dan DPRD. Namun, secara lebih luas, 


\section{AL-QISTH LAW REVIEW \\ VOL 5 NO. 1 (2021)}

fungsi parlemen itu sebenarnya dapat dibedakan dalam tiga macam, yaitu (Asshiddiqie, 2007):

(i) Fungsi pengaturan (legislasi);

(ii) Fungsi pengawasan (control); dan,

(iii) Fungsi perwakilan atau representasi.

Mengapa demikian, karena fungsi budgeting sendiri, pada pokoknya selalu dituangkan dalam bentuk undang-undang yang pelaksanannya juga harus diawasi oleh lembaga parlemen. Di samping fungsi legislasi dan pengawasan, masih ada pula fungsi lain yang belum tercakup dalam ketiga fungsi tersebut yang kurang mendapat perhatian. Misalnya, pentingnya fungsi perdebatan publik mengenai kebijakankebijakan tertentu yang menyangkut kepentingan rakyat luas sama sekali belum banyak disadari. Hal ini dapat dimasukkan dalam kelompok fungsi yang bersifat umum, yaitu fungsi representasi (Asshiddiqie, 2007).

Secara eksplisit dalam UUD NRI 1945, DPR diatur dalam BAB VII dengan judul Dewan Perwakilan Rakyat. BAB VII UUD NRI 1945 sendiri mengatur tentang kelembagaan DPR pada umumnya, yakni tentang tata cara pengisian anggota DPR melalui pemilihan umum, kekuasaan dan fungsi DPR, hak DPR dan hak Anggota DPR, serta pendelegasian pengaturan lebih lanjut berkenaan DPR dalam Undang-Undang. Hal inilah yang kemudian ditindaklanjuti dengan Undang-undang Nomor 2 Tahun 2018 tentang perubahan kedua atas Undang-undang Nomor 17 Tahun 2014 tentang MPR, DPR, DPR, dan DPRD. Hal yang menarik dalam 


\section{AL-QISTH LAW REVIEW \\ VOL 5 NO. 1 (2021)}

pengaturan tentang kelembagaan DPR dalam UU No. 2 Tahun 2018 adalah dikenalnya fraksi partai politik dalam kelembagaan DPR. Hal yang sama juga dijumpai dalam Undang-Undang Nomor 2 Tahun 2008 tentang Partai Politik.

Pasal 82 ayat (1) UU No. 2 Tahun 2018 menegaskan, bahwa fraksi merupakan pengelompokan anggota berdasarkan konfigurasi partai politik berdasarkan hasil pemilihan umum. Selain itu, pengaturan mengenai fraksi baik itu MPR, DPR, DPR, dan DPRD (Provinsi dan Kabupaten/Kota) juga diatur dalam Pasal 11, Pasal 80, Pasal 301 dan Pasal 352 UU No. 2 Tahun 2018. Dalam berbagai Pasal tersebut pada pokoknya mengharuskan setiap anggota legislatif untuk berhimpun dalam fraksi. Tujuan pembentukan fraksi ditentukan dalam Pasal 80 UU No. 2 Tahun 2018:

(1) untuk mengoptimalkan pelaksanaan fungsi, tugas dan wewenang DPR, serta hak dan kewajiban anggota DPR, dibentuk fraksi sebagai wadah berhimpun anggota DPR;

(2) Dalam mengoptimalkan pelaksanaan fungsi, tugas, dan wewenang $D P R$, serta hak dan kewajiban anggota DPR sebagaimana dimaksud pada ayat (1), fraksi melakukan evaluasi terhadap kinerja angota fraksinya dan melaporkan kepada publik.

Keberadaan fraksi berdasarkan UU No. 2 Tahun 2018 adalah sebatas pertimbangan dalam pemerataan atau keterwakilan penyusunan alat-alat kelengkapan maupun susunan lembaga legislatif agar sedapat 


\section{AL-QISTH LAW REVIEW \\ VOL 5 NO. 1 (2021)}

mungkin berfariasi guna pendistribusian anggota kedalam alat kelengkapan parlemen berdasarkan partainya, disamping itu juga banyak disebutkan mengenai peranan fraksi dalam memberikan pandangan ataupun pendapat yang berkaitan dengan tiga fungsi lembaga legislatif, yaitu legislasi, anggaran dan pengawasan. Namun dalam praktinya, keberadaan fraksi juga berimplikasi pada pembatasan hak-hak anggota legislatif secara pribadi yang membawa pesan dari konstituennya namun harus difilterisasi terlebih dahulu oleh fraksi partai politik, bahkan tidak jarang pimpinan partai politik yang secara langsung dapat mempengaruhi para anggotanya termasuk yang duduk sebagai anggota legislatif sekalipun.

Eksistensi fraksi di dalam kelembagaan Dewan Perwakilan Rakyat sebagai bentuk institusionalisasi partai politik nyatanya memiliki implikasi baik posistif maupun negatif. Sejatinya setiap anggota legislatif membawa mandat dari rakyat untuk melaksanakan fungsi pengawasan terhadap kinerja pemerintah. Namun melalui fraksi tidak jarang justru melemahkan atau bahkan mengesampingkan mandat tersebut untuk mengawasi kinerja pemerintah, baik mengenai penegakan hukum maupun pengawasan terhadap Anggaran Pendapatan dan Belanja Negara (APBN). Setiap anggota DPR harus tunduk kepada aturan main partai politik melalui fraksi, jika tidak, partai dapat mudah menarik atau memberhentikan anggota tersebut yang dengan sendirinya dapat menghilangkan jabatannya sebagai anggota legislatif. Hal tersebut sudah sering terjadi melalui mekanisme recall atau pemberhentian berdasarkan 


\section{AL-QISTH LAW REVIEW \\ VOL 5 NO. 1 (2021)}

usulan partai asalnya. Praktek-praktek seperti itulah yang mengakibatkan beralihnya kedaulatan rakyat kepada kedaulatan partai karena terhadap pelanggaran kedaulatan rakyat tidak ada mekanisme langsung untuk memberikan sanksi, biasanya hanya bersifat sanksi moral dan politik atau hanya berdampak pada popularitas tetapi jika bertentangan dengan kebijakan partai akan berakibat fatal.

Fraksi bukanlah alat kelengkapan Dewan Perwakilan Rakyat, akan tetapi eksistensi fraksi di Dewan Perwakilan Rakyat sangat mendominasi bahkan melebihi peran anggota Dewan Perwakilan Rakyat itu sendiri. Secara hukum, tujuan dibentuknya fraksi partai politik di Dewan Perwakilan Rakyat adalah untuk mengoptimalkan dan mengefektifkan pelaksanaan tugas, wewenang, hak dan kewajiban Dewan Perwakilan Rakyat. Namun dalam kenyataannya dengan keberadaan fraksi justru menjadi saluran tunggal untuk memaksakan kepentingan politik partai politik terhadap anggotanya di dalam kelembagaan Dewan Perwakilan Rakyat.

\section{b. Rumusan Masalah}

Berdasarkan uraian di atas, nampak bahwa eksistensi fraksi dalam kelembagaan DPR pada kenyataannya justru mengaburkan hakikat DPR sebagai pelembagaan kedaulatan rakyat. Fraksi dalam wujudnya sering tampil sebagai perpanjangan tangan partai politik, dan seringkali mengabaikan kepentingan rakyat. Penelitian ini dimaksudkan untuk menelaah hal dimaksud secara lebih dalam lagi. Berangkat dari uraian 


\section{1}

\section{AL-QISTH LAW REVIEW \\ VOL 5 NO. 1 (2021)}

tersebut, maka penelitian ini ingin menjawab permasalahan: Pertama, Bagaimana kedudukan fraksi partai politik dalam kelembagaan Dewan Perwakilan Rakyat?; Kedua, apakah implikasi keberadaan fraksi partai politik terhadap pelaksanaan fungsi Dewan Perwakilan Rakyat?

\section{c. Metode Penelitian}

Sesuai topik penelitian yakni meneliti eksistensi fraksi berdasarkan pengaturannya dalam Peraturan Perundang-Undangan, maka jenis penelitian ini adalah penelitian hukum normatif. Menurut Soerjono Soekanto dan Si Mamudji, yang dimaksud penelitian normative adalah penelitian hukum yang dilakukan dengan cara meneliti bahan psutaka atau data sekunder belaka, jenis penelitian inilah yang dikatakan sebagai penelitian hukum normatif. Penelitian hukum normatif mencakup: (i) penelitian terhadap asas-asas hukum; (ii) penelitian terhadap sistematika hukum; (iii) penelitian terhadap taraf singkronisasi vertical dan horizontal; (iv) perbandingan hukum; dan, (v) sejarah hukum. (Soekanto dan Mamudji, 2010).

Secara spesifik jenis penelitian yang memfokuskan pada bahan kepustakaan, baik yang bersifat primer, sekuder, tersier. Data primer adalah data yang berbentuk Peraturan Peraturan Perundang-Undangan, sedangkan data sekunder meliputi Buku-Buku, Artikel Ilmiah, Hasil Penelitian, dan Laporan yang dikeluarkan Lembaga Resmi. Tekni pengumpulan data ditempuh dengan melakukan penelitian kepustakaan dan studi dokumen. Adapun sumber data yang digunakan dalam 


\section{2}

\section{AL-QISTH LAW REVIEW \\ VOL 5 NO. 1 (2021)}

penelitian ini antara lain: 1) Bahan hukum primer, yakni bahan hukum yang memiliki kekuatan hukum mengikat. Dalam penelitian ini, bahan hukum primer dimaksud adalah meliputi, Undang-Undang Dasar Negara Republik Indonesia 1945, Undang-Undang, yaitu Undang-undang Nomor 2 Tahun 2018 tentang perubahan kedua atas Undang-undang Nomor 17 Tahun 2014 tentang MPR, DPR, DPR, dan DPRD, serta Undang-undang Nomor 2 Tahun 2011 tentang perubahan atas Undang-Undang Nomor 2 Tahun 2008 tentang Partai Politik. Bahan hukum sekunder, yakni bahan hukum yang membantu memberikan penjelasan terhadap bahan hukum primer. Bahan hukum sekunder ini meliputi buku yang ditulis oleh para ahli, jurnal, hasil penelitian dan sebagainya.

\section{B. PEMBAHASAN}

\section{a. Pelembagaan Kedaulatan Rakyat}

Baik sebelum maupun sesudah amandemen, UUD NRI 1945 telah secara tegas menyatakan bahwa kedaulatan berada di tangan rakyat. Hanya saja, rumusan kedaulatan sebelum dan sesudah amandemen UUD NRI 1945 memang berbeda. Sebelum amademen, rumusan tentang kedaulatan rakyat diatur dalam Pasal 1 ayat (2) UUD 1945: "Kedaulatan adalah di tangan rakyat, dan dilakukan sepenuhnya oleh Majelis Permusyawaratan Rakyat". Setelah amandemen, rumusan Pasal 1 ayat (2) UUD NRI 1945 diubah, sehingga menjadi: "Kedaulatan berada di tangan rakyat dan dilaksanakan menurut Undang-Undang Dasar". 


\section{3}

\section{AL-QISTH LAW REVIEW \\ VOL 5 NO. 1 (2021)}

Terlepas dari perbedaan rumusan kedaulatan dalam Pasal 1 ayat (2) UUD NRI 1945 sebelum dan sesudah amandemen yang membawa implikasi terhadap struktur ketatanegaraan di Indonesia, namun kedua rumusan perihal kedaulatan tersebut pada prinsipnya menegaskan bahwa Konstitusi Indonesia, yakni UUD NRI 1945 sejak awal perumusannya mengakui bahwa kekuasaan tertinggi dalam negara adalah berada di tangan rakyat. Dalam literature hukum dan politik, hal ini dikenal sebagai teori kedaulatan rakyat. Menurut teori ini, negara memperoleh kekuasaannya dari rakyatnya sendiri, bukan dari Tuhan atau Raja (Bakhri, 2017).

Dalam sejarahnya, pelaksanaan kedaulatan rakyat ini dilaksanaka baik secara langsung maupun secara tidak langsung. Dalam masyarakat yang masih sederhana, demokrasi dilaksanakan secara langsung seperti yang dipraktikkan di masa Yunani Kuno dalam konsep 'city state' atau negara kota. Akan tetapi dalam perkembangan masyarakat yang semakin kompleks dan dengan jumlah penduduk yang besar dan wilayahnya yang luas, demokrasi atau kedaulatan rakyat tidak mungkin silaksanakan secar langsung saja. Di samping demokrasi yang bersifat langsung, dibutuhkan juga mekanisme yang bersifat tidak langsung. Untuk itu umat manusia menciptakan lembaga perwakilan rakyat atau biasa disebut dengan parlemen (Asshiddiqie, 2007).

Di Indonesia sendiri, dalam struktur parlemennya terdapat tiga buah lembaga yang terpisah, yaitu DPR, DPR, dan MPR. Secara resmi, 


\section{4}

\section{AL-QISTH LAW REVIEW \\ VOL 5 NO. 1 (2021)}

seperti yang tercermin dalam ketentuan UU tentang Susunan dan Kedudukan MPR, DPR, DPR, dan DPRD, Dewan Perwakilan Rakyat (DPR) dapat disebut sebagai lembaga perwakilan rakyat, dan Dewan Perwakilan Daerah (DPD) adalah lembaga perwakilan daerah, sedangkan Majelis Permusyawaratan Rakyat (MPR) merupakan lembaga permusyawaratan rakyat. Akan tetapi, secara teoritis sebetulnya ketiga lembaga DPR, DPD, dan MPR itu mencerminkan struktur parlemen yang sangat khas Indonesia (Asshiddiqie, 2007).

DPR sendiri sebagai lembaga yang disebut lembaga perwakilan rakyat, memang memiliki kewenangan yang lebih kuat dibandingkan DPD dan MPR. Hal yang demikian misalnya diatur dalam Pasal 20 ayat (1) UUD NRI 1945: "DPR memegang kekuasaan membentuk undang-undang". Hal ini menunjukkan bahwa DPR memiliki kekuasaan legislatif. Cabang legislatif adalah cabang kekuasaan pertama yang mencerminkan asas kedaulatan rakyat. Kegiatan bernegara, pertam-tama adalah untuk mengatur kehidupan bersama. Karena itu, kewenangan untuk menetapkan peraturan itu pertama-tama harus diberikan kepada lembaga perwakilan rakyat atau parlemen atau legislative. Ada tiga hal penting yang harus diatur boleh para wakil rakyat melalui parlemen, yaitu (i) pengaturan yang dapat mengurani hak dan kebebasan warga negara, (ii) pengaturan yang dapat membebani harta kekayaan warga negara, dan (iii) pengaturan mengenai pengeluaran-pengeluaran oleh penyelenggara negara. Pengaturan mengenai ketiga hal tersebut hanya dapat dilakukan atas persetujuan dari warga negara sendiri, yaitu melalui perantara wakil- 


\section{5}

\section{AL-QISTH LAW REVIEW \\ VOL 5 NO. 1 (2021)}

wakil mereka di parlemen sebagai lembaga perwakilan rakyat (Asshiddiqie, 2007).

Jika merujuk kepada Pasal 20 ayat (1) UUD NRI 1945 yang menyatakan bahwa DPR sebagai pemegang kekuasaan membentuk undang-undang, ditambah dengan fungsi pengawasan dan anggaran, maka dari sisi kewenangan, DPR merupakan lembaga perwakilan yang paling mencerminkan asas kedaulatan rakyat atau dekan kata lain DPR adalah lembaga perwakilan rakyat.

\section{b. Eksistensi Fraksi Partai Politik Dalam Kelembagaan DPR}

Partai Politik merupakan suatu organisasi politik yang terdiri dari sekelompok individu dengan kepentingan sama dan berfungsi sebagai sarana rekruitmen politik, sarana sosialisasi politik, serta sarana mengatur konflik dalam rangka menunjang pelaksanaan kedaulatan rakyat (Cahyawati, 2019, p. 35).

Dalam Pasal 1 ayat (1) Undang-Undang Nomor 2 Tahun 2011 Tentang Perubahan Atas Undang-undang Nomor 2 Tahun 2008 Tentang Partai Politik, menentukan partai politik adalah organisasi yang bersifat nasional dan dibentuk oleh sekelompok warga Negara Indonesia secara sukarela atas dasar kesamaan kehendak dan cita-cita untuk memperjuangkan dan membela kepentingan politik anggota masyarakat, bangsa dan Negara serta memelihara keutuhan Negara Kesatuan Republik Indonesia berdasarkan pancasila dan Undang-Undang Dasar Negara 


\section{AL-QISTH LAW REVIEW \\ VOL 5 NO. 1 (2021)}

Republik Indonesia Tahun 1945. Dalam prespektif kelembagaan partai politik adalah mata rantai yang menghubungkan antara rakyat dengan penyelenggara Negara.

Dalam menghubungkan aspirasi dan kehendak rakyat dengan penyelenggaraan negara, partai politik menjadi wadah dalam proses pemilihan umum, yang salah satunya untuk memilih wakil rakyat yang duduk di DPR. Dalam konteks ini, dipahami bahwa partai politik merupakan sebuah kendaraan bagi masyarakat untuk ikut berpartisipasi dalam proses yang demokratis (pemilihan umum), yang jika terpilih maka akan menduduki jabatan atau keanggotaan tertentu, seperti DPR, DPRD, Presiden dan/atau Wakil Presiden, Gubernur, dan Bupati serta Walikota.

Hal yang demikian sejalan dengan apa yang dikemukakan oleh Ramlan Surbakti (Surbakti, 1992), bahwa Fungsi utama partai politik ialah mencari dan mempertahankan kekuasaan guna mewujudkan programprogram yang disusun berdasarkan ideologi tertentu. Penjelasan tersebut merupakan cara yang digunakan oleh partai politik di dalam sistem politik demokrasi untuk mendapatkan dan mempertahankan kekuasaan dalam keikutsertaan dalam pemilihan umum. Ketika partai politik melaksanakan fungsinya dalam system politik demokrasi setidaknya ada beberapa hal yang perlu dilakukan, yaitu melakukan rekruitmen, kampanye, dan melaksanakan fungsi pemerintahan. Semua hal tersebut semata-mata dilakukan untuk menunjang pelaksanaan kedaulatan rakyat yang berorientasi pada kepentingan rakyat. 


\section{7}

\section{AL-QISTH LAW REVIEW \\ VOL 5 NO. 1 (2021)}

Partai politik sebagai organisasi politik yang dibentuk oleh masyarakat atau kelompok masyarakat yang memiliki kesamaan ideologi dimaksudkan untuk mengimplementasikan kepentingan rakyat melalui bidang politik. Hal tersebut sesuai dengan amanat yang dituangkan dalam pasal 11 ayat (1) Undang-Undang Nomor 2 Tahun 2011 Tentang Perubahan Atas Undang-Undang Nomor 2 Tahun 2008 Tentang Partai Politik, yang menegaskan bahwa "Partai politik berfungsi sebagai sarana penyerap, penghimpun, dan penyalur aspirasi politik masyarakat dalam merumuskan dan menetapkan kebijakan Negara." Selain itu partai politik juga berfungsi sebagai sarana sosialisasi dan pendidikan politik bagi warga Negara yang tertarik pada politik untuk mengembangkan potensinya ataupun kopetensinya di dalam bidang politik. Selain itu, partai politik juga berfungsi sebagai sarana peredam dan pengatur konflik serta sebagai komunikasi politik.

Jika melihat kepada fungsi dan kedudukan partai politik dalam UUD NRI 1945, maka diketahui bahwa partai politik diposisikan sebagai salah satu pilar demokrasi yang berfungsi sebagai wadah bagi warga negara untuk menyalurkan aspirasinya. Dengan demikian, fungsi partai poltik sesungguhnya hanya sampai pada tahap rekrutmen dan keikutsertaan dalam proses demokrasi yang disebut pemilihan umum. Namun dalam pengaturan kemudian, ternyata tidak hanya sampai di situ saja. Peran parati politik mempengaruhi kelembagaan parlemen, khususnya di Dewan Perwakilan Rakyat. 


\section{8}

\section{AL-QISTH LAW REVIEW \\ VOL 5 NO. 1 (2021)}

Hal yang demikian di atur dalam Pasal 82 ayat (1) Undang-Undang Nomor 2 Tahun 2018 Tentang Perubahan Kedua Atas Undang-Undang Nomor 17 Tahun 2014 Tentang Majelis Permusyawaratan Rakyat, Dewan Perwakilan Rakyat, Dewan Perwakilan Daerah dan Dewan Perwakilan Rakyat Daerah yang menyatakan bahwa fraksi merupakan pengelompokan anggota berdasarkan konfigurasi partai politik berdasarkan hasil pemilihan umum. Pasal ini menjadi dasar diintitusionalkannya partai politik di dalam kelembagaan Dewan Perwakilan Rakyat.

Amien Rais dalam bukunya menuliskan, partai politik sejatinya hari ini tentunya menjadi sebuah sorotan utama dikalangan masyarakat, terutama memperhatikan anggotanya diparlemen dan kader partai yang berkecimpung di pemerintahan serta implementasi kepentingan rakyat menjadi bagian yang tidak bisa dipisahkan dalam proses berlangsungnya partai politik ditengah kehidupan masyarakat (Rais, 1986). Sejatinya setiap partai politik memiliki kepentingan, baik untuk mendapatkan kekuasaan atau mempertahankan kekuasaan. Sedangkan kepentingan rakyat menuju pada kesejahteraan rakyat, bangsa dan Negara serta terjaminnya keamanan dan ketertiban agar rakyat merasa aman dengan kehadiran Negara di tengah-tengahnya. Oleh karena itulah kepentingan rakyat jauh lebih penting dari kepentingan partai politik.

Fraksi yang ada di dalam kelembagaan Dewan Perwakilan Rakyat merupakan bagian dari struktural partai politik, perpanjangan tangan 


\section{9}

\section{AL-QISTH LAW REVIEW \\ VOL 5 NO. 1 (2021)}

partai politik dan alat perjuangan partai politik yang memiliki kursi di Dewan Perwakilan Rakyat yang mana komposisi pengurus fraksi diangkat, disahkan dan diberhentikan oleh ketua umum partai politik. Bahkan pengurus partai politik yang bukan anggota Dewan Perwakilan Rakyat dapat memimpin rapat, memberi arahan, memberi pendapat dan kebijakan fraksi dari partai politik. Oleh karena itu, dalam memberikan arahan maupun kebijakan untuk mengoptimalkan pelaksanaan fungsi Dewan Perwakilan Rakyat, fraksi partai politik dituntut untuk memepentingkan kepentingan rakyat.

Keberadaan fraksi dalam kelembagaan DPR, terkait juga dengan fungsi partai politik itu sendiri. Sejalan dengan hal tersebut, Miriam Budiardjo mengemukakan (Budiardjo, 1994), bahwa pada umumnya partai politik juga diharapkan akan melaksanakan fungsi seperti dinegara yang sudah mantap kehidupan politiknya. Diharapkan menjadi alat penting untuk mengorganisir kekuasaan politik, mempengaruhi keputusan-keputusan pemerintah serta turut melaksanakannya, menghubungkan secara efektif masyarakat umum dengan proses politik, merumuskan asirasi dan tuntutan rakyat serta memasukannya kedalam proses pembuatan keputusan.

Hubungan fraksi partai politik dengan Dewan Perwakilan Rakyat bertumpu pada Undang-undang mengenai lembaga perwakilan rakyat yaitu Undang-Undang Nomor 2 Tahun 2018 Tentang Perubahan Kedua Atas Undang-Undang Nomor 17 Tahun 2014 Tentang Majelis 


\section{AL-QISTH LAW REVIEW \\ VOL 5 NO. 1 (2021)}

Permusyawaratan Rakyat, Dewan Perwakilan Rakyat, Dewan Perwakilan Daerah dan Dewan Perwakilan Rakyat Daerah. Pasal 82 menyatakan bahwa:

(1) Fraksi merupakan pengelompokan anggota berdasarkan konfigurasi anggota partai politik peserta pemilu;

(2) Setiap anggota Dewan Perwakilan Rakyat harus menjadi anggota fraksi;Fraksi dibentuk oleh partai politik yang memenuhi ambang batas;

(3) perolehan suara dalam penentuan perolehan kursi Dewan Perwakilan Rakyat;

(4) Fraksi dibentuk untuk mengoptimalkan pelaksanaan fungsi, wewenang, tugas Dewan Perwakilan Rakyat serta hak dan kewajiban anggota Dewan Perwakilan Rakyat;

(5) Fraksi didukung oleh sekertariat dan tenaga ahli;

(6) Sekertariat jenderal Dewan Perwakilan Rakyat menyediakan sarana, anggaran dan tenaga ahli guna kelancaran pelaksanaan tugas fraksi;

(7) Ketentuan lebih lanjut mengenai sarana dan tenaga ahli fraksi sebagaimana diatur dalam ayat (6) diatur dalam peraturan Dewan Perwakilan Rakyat.

Selain Undang-Undang Nomor 2 Tahun 2018 Tentang Peubahan Kedua Atas Undang-Undang Nomor 17 Tahun 2014 Tentang Majelis Permusyawaratan Rakyat, Dewan Perwakilan Rakyat, Dewan Perwakilan Daerah dan Dewan Perwakilan Rakyat Daerah, ketentuan mengenai fraksi partai politik juga diatur dalam Peraturan Dewan Perwakilan Rakyat Republik Indonesia Nomor 2 Tahun 2018 Tentang Perubahan Ketiga Atas 


\section{1}

\section{AL-QISTH LAW REVIEW \\ VOL 5 NO. 1 (2021)}

Peraturan Dewan Perwakilan Rakyat Republik Indonesia Nomor 1 Tahun 2014 Tentang Tata Tertib Dewan Perwakilan Rakyat, yang merumuskan bahwa ;

\section{Pasal 20}

(1) Fraksi dibentuk untuk mengoptimalkan pelaksanaan fungsi, wewenang dan tugas Dewan Perwakilan Rakyat serta hak dan kewajiban anggota.

(2) Fraksi dibentuk oleh partai politik yang memenuhi ambang batas perolehan suara dalam penentuan perolehan kursi Dewan Perwakilan Rakyat.

(3) Fraksi juga dapat dibentuk oleh gabungan dari dua atau lebih partai politik sebagaimana dimaksud ayat (2).

(4) Setiap anggota harus menjadi salah satu fraksi.

(5) Fraksi bertugas mengkoordinasikan kegiatan anggotanya dalam melaksanakan wewenang dan tugas Dewan Perwakilan Rakyat serta meningkatkan kemampuan, disiplin, keefektifan dan efisiensi kerja anggotanya dalam melaksanakan tugas yang tercermin dalam setiap kegiatan Dewan Perwakilan Rakyat.।

(6) Fraksi melakukan evaluasi terhadap kinerja anggotanya dan melaporkan kepada public paling sedikit satu kali dalam satu tahun siding.

(7) Pimpinan fraksi di tetapkan oleh fraksinya masing-masing.

(8) Fraksi membentuk aturan tata kerja internal sesuai dengan ketentuan peraturan perundang-undangan.

\section{Pasal 21}

(1) Fraksi didukung oleh sekertariat dan tenaga ahli. 


\section{2}

\section{AL-QISTH LAW REVIEW \\ VOL 5 NO. 1 (2021)}

(2) Sekertariat fraksi ditetapkan oleh sekertaris jenderal Dewan Perwakilan Rakyat dengan persetujuan pimpinan fraksi.

(3) Tenaga ahli pada setiap fraksi paling sedikit sejumlah alat kelengkapan Dewan Perwakilan Rakyat dan mendapat tambahan secara proposional berdasarkan jumlah anggota setiap fraksi.

(4) Rekrutmen tenaga ahli fraksi dilakukan oleh pimpinan fraksi dan hasil rekrutmen disampaikan kepada sekertaris jenderal Dewan Perwakilan Rakyat untuk ditetapkan dengan keputusan sekertaris jenderal Dewan Perwakilan Rakyat.

(5) Rekrutmen tenaga ahli fraksi sebagaimana dimaksud pada ayat (4) didasarkan pada kompetisi keahlian yang ditentukan oleh pimpinan fraksi.

(6) Fraksi mengajukan anggaran serta kebutuhan sekertariat dan tenaga ahli fraksi kepada Badan Urusan Rumah Tangga.

(7) Badan Urusan Rumah Tangga meneruskan usulan fraksi sebagaimana dimaksud pada ayat (6) kepada sekertaris jenderal Dewan Perwakilan Rakyat untuk di tindak lanjuti.

Berdasarkan ketentuan di atas, dapat diketahui bahwa fraksi partai politik merupakan pengelompokan anggota-anggota fraksi partai politik yang ada di dalam kelembagaan Dewan Perwakilan Rakyat. Hal yang demikian berarti bahwa fraksi partai politik merupakan bentuk institusionalisasi partai politik dalam kelembagaan DPR atau dengan kata lain merupakan kepanjangan tangan partai politik di dalam tubuh DPR.

\section{c. Implikasi keberadaan Fraksi Partai Politik Terhadap Pelaksanaan Fungsi Dewan Perwakilan Rakyat}




\section{3}

\section{AL-QISTH LAW REVIEW \\ VOL 5 NO. 1 (2021)}

Dalam pelaksanaan fungsi Dewan Perwakilan Rakyat, eksistensi fraksi sangat mendominasi dari pada peran anggota Dewan Perwakilan Rakyat itu sendiri. Di antaranya ialah pimpinan Dewan Perwakilan Rakyat dalam menjalankan tugas harus sesuai dengan intruksi fraksi yang mana fraksi merupakan perpanjangan tangan partai politik yang ada di dalam kelembagaan Dewan Perwakilan Rakyat, sedangkan tugas Dewan Perwakilan Rakyat dalam menjalankan fungsi Dewan Perwakilan Rakyat mestinya dilakukan oleh anggota Dewan Perwakilan Rakyat itu sendiri dan tidak perlu lagi mempertimbangkan pendapat fraksi karena fraksi bukan alat kelengkapan Dewan Perwakilan Rakyat. Selain besarnya campur tangan fraksi dalam pelaksanaan fungsi Dewan Perwakilan Rakyat, ternyata fraksi juga sangat menentukan komposisi keanggotaan, mengusulkan nama anggota dan mengganti anggota. Oleh karena itu Ramlan Surbakti berpendapat bahwa ketentuan tentang fraksi yang diatur dalam Tata Tertib Dewan Perwakilan Rakyat merupakan salah satu sumber kekuasaan politik fraksi (Surbakti, 2007).

Untuk mempertahankan dan memperkuat hubungan dalam kelembagaan Dewan Perwakilan Rakyat maka dibuatlah aturan yang sedemikian rupa sehingga fraksi dengan mudahnya tetap eksis dalam mencampuri urusan rumah tangga rakyat melalui wakil rakyat yang ada di Dewan Perwakilan Rakyat. Selain diberi ruang oleh Undang-Undang Dasar 1945 dan Undang-Undang mengenai Partai politik, nampaknya partai politik juga diberi kewenangan dalam menentukan nasib wakil rakyat yang ada di Dewan Perwakilan Rakyat. Oleh karena itu dibuatlah 


\section{4}

\section{AL-QISTH LAW REVIEW \\ VOL 5 NO. 1 (2021)}

format dalam pasal 239 ayat (2) Undang-Undang Nomor 2 Tahun 2018 Tentang Perubahan Kedua Atas Undang-Undang Nomor 17 Tahun 2014 Tentang Majelis Permusyawaratan Rakyat, Dewan Perwakilan Rakyat, Dewan Perwakilan Daerah dan Dewan Perwakilan Rakyat Daerah yang menegaskan bahwa ;

(1) Anggota DPR berhenti antar waktu karena:

a. Meninggal dunia;

b. Mengundurkan diri; atau

c. Diberhentikan

(1) Anggota DPR diberhentikan antar waktu sebagaimana dimaksud pada ayat (1) huruf C apabila :

(2) Tidak dapat melaksanakan tugas secara berkelanjutan atau berhalangan tetap sebagai anggota DPR selama 3 (tiga) bulan berturut-turut tanpa keterangan apapun;

(3) Melanggar sumpah atau janji dan kode etik DPR;

(4) Dinyatakan bersalah berdasarkan putusan pengadilan yang telah memperoleh kekuatan hukum tetap karena melakukan tindak pidana yang diancam dengan pidana penjara 5 (lima) tahun atau lebih;

(5) Diusulkan oleh partai politiknya sesuai ketentuan peraturan perundangundangan;

(6) Tidak lagi memenuhi syarat sebagai calon anggota DPR sesuai dengan ketentuan peraturan perundang-undangan mengenai pemiluhan umum anggota DPR, DPD dan DPRD; 


\section{5}

\section{AL-QISTH LAW REVIEW \\ VOL 5 NO. 1 (2021)}

(7) Melanggar ketentuan larangan sebagaimana diatur dalam Undangundang ini;

Diberhentikan sebagai anggota partai politik sesuai dengan ketentuan peraturan perundang-undangan atau menjadi anggota partai politik. Pergantian Antar Waktu atau sering dikenal dengan istilah PAW yang diusulkan oleh partai politik terhadap pergantian anggota Dewan Perwakilan Rakyat, menjadikan suatu penjelasan bahwa memang peran partai politik didalam kelembagaan Dewan Perwakilan Rakyat lebih mendominasi dari peran Dewan Perwakilan Rakyat yang merupakan wakil dari rakyat. Hal seperti inilah yang mejadikan anggota Dewan Perwakilan Rakyat tidak bisa bergerak, berfikir, dan tidak bisa mengambil keputusan sesuai dengan apa yang memang diinginkan oleh rakyat, sehingga konsep kepentingan rakyat berubah menjadi konsep kepentingan partai politik. Selain itu, kewenangan besar yang dimiliki oleh partai politik mendesak anggota Dewan Perwakilan Rakyat harus tunduk pada aturan main partai politik, apabila tidak tunduk kepada partai politik maka anggota Dewan Perwakilan Rakyat dengan sendirinya dapat kehilangan jabatannya sebagai wakil rakyat. Jika dilihat dari format Undang-undang mengenai lembaga perwakilan rakyat memang politik hukum Undang-undang mengenai lembaga perwakilan rakyat di desain untuk lebih menguntungkan kepentingan partai politik dari pada kepentingan rakyat. 


\section{6}

\section{AL-QISTH LAW REVIEW \\ VOL 5 NO. 1 (2021)}

\section{PENUTUP}

Berdasarkan hasil pembahasan di atas, maka penelitian ini menarik kesimpulan sebagai berikut: Pertama, keberadaan fraksi partai politik didalam kelembagaan Dewan Perwakilan Rakyat nampaknya telah menunjukan bahwa eksistensinya cenderung lebih mementingkan kepentingan partai politik daripada kepentingan rakyat. Hal tersebut disebabkan karena wakil rakyat yang dipilih oleh rakyat dalam pemilihan umum lebih menonjolkan dirinya sebagai wakil dari partai politik. Oleh karena itu, apabila wakil rakyat dalam hal ini ialah anggota Dewan Perwakilan Rakyat masih tetap menjadi kader partai politik ataupun petugas partai politik maka akan terus berpotensi menimbulkan dua konflik kepentingan yaitu kepentingan rakyat dengan kepentingan partai politik. Akibatnya adalah anggota Dewan Perwakilan Rakyat akan cenderung melaksanakan segala perintah partai yang berorientasi pada kepentingan partai politik karena apabila tidak mengamini perintah partai maka partai politik dengan mudahnya dapat memberhentikan anggota Dewan Perwakilan Rakyat tersebut yang dengan sendirinya akan kehilangan jabatannya sebagai wakil rakyat. Karena dalam pelanggaran terhadap kepentingan rakyat hanya mendapatkan sanksi moral dari konstituen serta tidak berpengarug terhadap nasibnya sebagai wakil rakyat. Tetapi apabila anggota Dewan Perwakilan Rakyat bertententangan dengan kepentingan partai maka akan berakibat fatal. Oleh karena itu, eksistensi fraksi dalam membantu optimalisasi fungsi Dewan Perwakilan Rakyat perlu ditingkatkan, baik dalam pelaksanaan fungsi legislasi, fungsi anggaran maupun fungsi pengawasan. Dalam rangka meningkatkan kualitas wakil rakyat maka partai 


\section{7}

\section{AL-QISTH LAW REVIEW \\ VOL 5 NO. 1 (2021)}

politik wajib menerapkan Pendidikan politik terhadap kader partai politik sehingga partai politik dapat mencetak kader-kader partai yang mampu berkontribusi bagi kepentingan rakyat.

Kedua, implikasi keberadaan fraksi partai politik dalam kelembagaan Dewan Perwakilan Rakyat berakibat pada tergerusnya esensi anggota DPR sebagai wakil rakyat, menjadi wakil partai. Hal yang demikian dikarenakan keberadaan fraksi memberikan ruang bagi partai politik untuk leluasa mengendalikan anggota DPR yang berasal dari partainya untuk mengambil keputusan sesuai apa yang dikehendaki partai. Secara personal, hal ini secara jelas merupakan bentuk intervensi partai politik kepada setiap anggota DPR. Sedangkan secara kelembagaan, berbagai keputusan yang diambil dalam rangka menjalankan fungsi DPR sebagai lembaga perwakilan rakyat, sarat akan intervensi dari partai politik. 


\section{8}

\section{AL-QISTH LAW REVIEW \\ VOL 5 NO. 1 (2021)}

\section{DAFTAR PUSTAKA}

Asshiddiqie, J. (2007). Pokok-Pokok Hukum Tata Negara Indonesia Pasca Reformasi, Jakarta: PT. Bhuana Ilmu Populer.

Bakhri, S. (2017). Ilmu Negara Dalam Pergumulan Filsafat, Sejarah Dan Negara Hukum (Cetakan ke-1). Depok: Rajawali Pers.

Budiardjo, M. (1994), Demokrasi Di Indonesia Demokrasi Parlementer Dan Demokrasi Pancasila. Jakarta: PT. Gramedia Pustaka Utama.

Sirajuddin dan Winardi. (2005). Dasar-Dasar Hukum Tata Negara Indonesia. Malang: Setara Press.

Soekanto, S. dan Mamudji, S. (2010) Penelitian Hukum: Suatu Tinjauan Singkat. Jakarta: Rajawali Press.

Surbakti, R. (1992). Memahami Ilmu politik. Jakarta : PT. Gramedia.

Rais, M. A. (1986). Demokrasi dan Proses Politik. Jakarta: Lembaga Penelitian Pendidikan dan Penerangan Ekonomi dan Sosial.

Indonesia. Undang-Undang Dasar Negara Republik Indonesia Tahun 1945. 


\section{9}

\section{AL-QISTH LAW REVIEW \\ VOL 5 NO. 1 (2021)}

Indonesia. (2018). Undang-undang Nomor 2 Tahun 2018 tentang perubahan kedua atas Undang-undang Nomor 17 Tahun 2014 tentang MPR, DPR, DPR, dan DPRD. Jakarta, Diakses dari https:// peraturan.bpk.go.id/Home/Details/72791/uu-no-2-tahun2018

Indonesia. (2011). Undang-Undang Nomor 2 Tahun 2011 Tentang Perubahan Atas Undang-undang Nomor 2 Tahun 2008 Tentang Partai Politik. Jakarta, Diakses dari https:/ / peraturan.bpk.go.id/Home/Details/38859/uu-no-2-tahun2011 